\title{
EKSTRAKSI FLAVONOID DARI TEMU IRENG (Curcuma aeruginosa Roxb) DAN APLIKASINYA PADA SABUN TRANSPARAN
}

\author{
Alvika Meta Sari ${ }^{1}$, Erba Vidya Cikta ${ }^{1}$ \\ 'Jurusan Teknik Kimia, Fakultas Teknik, Universitas Muhammadiyah Jakarta \\ alvika.metasari@umj.ac.id
}

\begin{abstract}
ABSTRAK. Temu ireng (Curcuma aeruginosa Roxb) merupakan salah satu dari sekian tanaman obat tradisional yang ada di Indonesia yang diketahui mengandung flavonoid. Flavonoid ini dapat berfungsi sebagai antioksidan dan antimikroba. Sedangkan pemanfaatan temu ireng masih sebatas sebagai obat tradisional. Maka perlu ada pemanfaatan temu ireng pada bidang yang lain. Penelitian ini bertujuan untuk mendapatkan ekstrak temu ireng dengan metode ekstraksi maserasi, mencari pengaruh waktu maserasi terhadap rendemen ekstrak flavonoid dari temu ireng, mendapatkan waktu maserasi yang optimal dan membuat sabun padat transparan dengan penambahan ekstrak temu ireng. Pada penelitian ini dilakukan ekstraksi maserasi dalam pelarut metanol 96\% volume dan ratio volume pelarut 1:5 dengan lama waktu maserasi divariasikan 4 jam, 8 jam, 12 jam, 16 jam, dan 24 jam untuk mendapatkan flavonoid dari temu ireng. Hasilnya dianalisis dengan uji warna, dan diukur absorbansinya menggunakan spektrofotometer UV-Vis. Hasil ekstrak flavonoid temu ireng (Curcuma aeruginosa) dibandingkan dengan pembanding kuersetin dimana dalam standar tersebut telah diketahui pasti kandungan flavonoid. Ekstrak yang terbaik lalu ditambahkan pada pembuatan sabun padat transparan. Semakin lama waktu maserasi semakin besar rendemen yang didapatkan. Hasil rendemen terbaik didapatkan pada waktu maserasi 24 jam sebesar 7,83\%. Hubungan antara variabel waktu maserasi terhadap rendemen (\% massa) dapat disajikan dengan persamaan $y=$ $0.002 x+0.012$ dengan $R^{2}=0.989$ dan kadar flavonoid terbaik yang didapat adalah 3.5 $\mathrm{g} / \mathrm{mL}$ dengan persamaan $y=0.114 x+1.050$ dengan $R^{2}=0.879$. Sabun padat transparan yang dihasilkan mempunyai $\mathrm{pH}$ 9, kandungan alkali 0,048 dan kadar air 0,31 .
\end{abstract}

Kata kunci: Temu ireng, maserasi, flavonoid, sabun padat transparan

\section{PENDAHULUAN}

Temu ireng (Curcuma aeruginosa Roxb) merupakan salah satu tanaman obat di Indonesia. Temu ireng diketahui mengandung saponin, flavonoid, amilum, lemak, zat pahit, zat warna biru, tannin dan polifenol juga minyak atsiri $0,3-2 \%$ (Syamsulhidayat dan Hutapea, 1991, Gunawan dkk., 1989). Saat ini pemanfaatan temu ireng masih terbatas pada obat tradisional yaitu sebagai obat batuk. Padahal melihat kandungan dalam temu ireng, potensi pemanfaatan temu ireng dapat lebih luas yaitu dengan penggunaan flavonoid pada berbagai aplikasi.
Flavonoid merupakan senyawa polifenol. Senyawa ini merupakan turunan dari 2-fenil kromon atau 2-fenil benzopiron. Fungsi dari flavonoid dapat menyembuhkan radang karena senyawa ini mempunyai efek anti bakteri, anti virus, antiseptik, antihistamin (Willaman, 1955), reduktor, antihipertensi (Nugahaningtyas dkk, 2005), merangsang pembentukan estrogen (Robinson, 1955), antifungal dan insektisidal (Geissman, 1962).

Oleh karena itu pada penelitian ini dilakukan ekstraksi maserasi untuk mendapatkan ekstrak flavonoid. Maserasi dipilih karena alat yang diperlukan sederhana, prosesnya hemat penyari, dan tanpa pemanasan sehingga biaya yang dibutuhkan lebih 
rendah dibandingkan dengan metode yang lain. Ekstraks flavonoid yang dihasilkan lalu diaplikasikan pada sabun padat transparan sebagai antioksidan. Sabun padat transparan dipilih karena mempunyai nilai ekonomis yang lebih tinggi dibandingkan dengan sabun yang lain.

\section{METODOLOGI PENELITIAN}

\section{Bahan dan Alat}

Bahan - bahan yang digunakan dalam ekstraksi adalah temu ireng, metanol, aquades, kuersetin dan indikator PP. Sedangkan bahan untuk pembuatan sabun padat transparan adalah minyak kelapa, $\mathrm{NaOH}, \mathrm{KOH}$, asam stearat, gliserin, etanol, dan gula pasir.

Alat - alat yang digunakan adalah labu ukur, beaker glass, erlenmeyer, kertas saring, pisau, gelas ukur, pengaduk, pemanas, peralatan saring vakum, alat destilasi vakum, $\mathrm{pH}$ indicator universal, termometer, pendingin tegak, oven, buret, statif dan klem.

\section{Metode Penelitian}

\section{Pembuatan Ekstrak Temu Ireng}

Rimpang temu ireng dicuci hingga bersih lalu dipotong halus, diangin - anginkan pada suhu kamar sampai kering. Lalu dihaluskan menggunakan blender sampai berbentuk serbuk. Serbuk ditimbang sebanyak 6 gam lalu dimasukkan ke dalam bejana maserasi. Proses ekstraksi maserasi dilakukan di dalam wadah yang tertutup dengan penambahan pelarut metanol dengan rasio volume 1:5 pada variasi waktu maserasi 4, 8, 12, 16 dan 24 jam. Hasil ekstraksi disaring. Filtrat yang didapatkan lalu dipekatkan dengan cara destilasi vakum pada suhu 50 $55^{\circ} \mathrm{C}$ tekanan $0,06 \mathrm{~Pa}$. Lalu dihitung rendemen yang didapat. Hasilnya diuji kadar flavonoid dengan menggunakan spektrofotometer UV-Vis. Hasil ekstrak dengan kadar flavonoid terbaik ditambahkan untuk pembuatan

sabun

padat transparan.

2. Pembuatan kurva larutan standar kuersetin

Larutan kuersetin dibuat dengan konsentrasi 1, 2, 3, 4 dan 5 ppm dengan melarutkan larutan standar kuarsetin 100 ppm $\quad(10 \quad \mathrm{mg}$ kuersetin dilarutkan dalam $100 \mathrm{~mL}$ dalam larutan metanol teknis $70 \%$ volum). Masing - masing larutan standar kuersetin diukur absorbansinya pada spektrofotometer UV-Vis dengan panjang gelombang $370 \mathrm{~nm}$.

Hasil dari absorbansi dibuat gafik regesi linear dengan persamaan (1).

$$
\begin{array}{cc}
y=a & x+b \ldots \ldots \ldots \ldots . . . \\
\text { Dengan } & y=\text { nilai absorbansi } \\
x & =\text { kadar flavonoid } \\
a, b & =\text { konstanta }
\end{array}
$$

\section{Pembuatan Sabun Padat Transparan}

Asam stearat sebanyak $15 \mathrm{~g}$ dipanaskan pada suhu $60^{\circ} \mathrm{C}$. Minyak kelapa sebanyak $50 \mathrm{~mL}$ dipanaskan sampai suhu $60^{\circ} \mathrm{C}$. Larutan $\mathrm{NaOH}$ 30\% dimasukkan sebanyak $25 \mathrm{~mL}$. Campuran lalu dipanaskan dengan suhu $70^{\circ} \mathrm{C}$ sambil diaduk sampai proses saponifikasi sempurna (terbentuk larutan kental). Lalu ditambahkan asam stearat yang sudah dilelehkan. Kemudian ditambahkan $40 \mathrm{~mL}$ etanol, $40 \mathrm{~mL}$ gliserin dan 4 $\mathrm{g}$ gula pasir sambil terus diaduk. Setelah terbentuk larutan yang transparan dimasukkan ekstrak temu ireng pada suhu terbaik dan diaduk kembali sampai homogen. Setelah itu campuran dituang ke dalam cetakan.

\section{Metoda Uji}

1. Metode Uji Hasil Rendemen Hasil rendemen dihitung dengan persamaan (2).

$$
\begin{aligned}
& \text { Kendemen }= \\
& \frac{\text { berat Ekstrax }}{\text { berat Temulrang }} \times 100 \%
\end{aligned}
$$


2. Metode Uji Kadar Flavonoid.

Uji kadar flavonoid dilakukan dengan penentuan panjang gelombang flavonoid menggunakan alat Spektrofotometer UV-Vis. Hasilnya dibandingkan dengan panjang gelombang larutan standar Kuersetin dengan konsentrasi 100 ppm. Larutan standard dibaca absorbansi pada gelombang 300 $500 \mathrm{~nm}$.

3. Uji pH Sabun

Sampel sabun padat transparan yang dihasilkan ditimbang sebanyak $10 \mathrm{~g}$ dan dilarutkan dalam $100 \mathrm{~mL}$ air. Lalu dimasukkan indicator $\mathrm{pH}$ universal ke dalam sampel. Perubahan warna yang terjadi disesuaikan dengan skala yang sudah ditetapkan.

4. Uji Kadar Air Sabun

Uji kadar air dilakukan dengan metode oven. Cawan kosong ditimbang (ditetapkan sebagai $W_{1}$ ). Sampel sebanyak $4 \mathrm{~g}$ ditimbang lalu dipanaskan dalam oven selama 3 jam hingga diperoleh berat konstan. Sampel dan cawan yang sudah ditimbang (ditetapkan sebagai $W_{2}$ ). Kadar air dihitung dengan persamaan (3).

\section{Kadar $\mathrm{A} i \mathrm{~T}=$ \\ $\frac{\text { Berat Sampel }-\left(W_{2}-W_{1}\right)}{\text { Beratsampei }} \times 100 \%$ \\ ...... (3)}

5. Uji Alkali Bebas atau asam lemak bebas

Alkohol sebanyak $50 \mathrm{~mL}$ dididihkan dalam labu erlenmeyer $250 \mathrm{~mL}$, ditambahkan fenolftalin 3 tetes dan didinginkan lalu sampel dinetralkan dengan $\mathrm{KOH}$ 0,1 $\mathrm{N}$ dalam alkohol. Lalu dimasukkan sampel sabun sebanyak $5 \mathrm{~g}$, lalu dipasang pendingin tegak dan dipanaskan sampai larutan homogen. Apabila larutan tidak bersifat alkalis (tidak berwarna merah), sampel didinginkan sampai $70^{\circ} \mathrm{C}$ dan dititrasi dengan larutan $\mathrm{KOH} 0,1 \mathrm{~N}$ dalam alkohol hingga timbul warna merah yang ditahan selama 15 detik. Hasil kemudian dihitung menggunakan persamaan (4).

Asum lemak bebas $=$

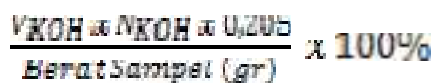

$0,205=$ berat setara asam laurat

Bila larutan tersebut bersifat alkali (berwarna merah) maka yang diuji bukan asam lemak bebas tetapi alkali bebas, yaitu dengan cara mentitrasi menggunakan $\mathrm{HCl} 0,1 \mathrm{~N}$ sampai warna merah tepat hilang. JumLah alkali bebas dihitung dengan persamaan (5).

Alkali bebas $=$

$\frac{v_{\mathrm{KOH}} \times \mathrm{N}_{\mathrm{KOH}} \mathrm{W} \mathrm{UN} 4}{\text { berat3ampel (gr) }} \times 100 \%$

6. Analisis data.

Analisis data menggunakan analisa korelasi dengan nilai sandaran $-1 \leq$ $r \leq 1$. Semakin tinggi nilai koefisien korelasi (mendekati nilai 1) maka hubungan antara dua variabel tersebut semakin tinggi pula. Tapi kebalikannya jika nilai koefisien mendekati 0 maka hubungannya semakin rendah. Jika bertanda negatif maka hubungan yang terjadi berlawanan arah artinya suatu variabel naik maka nilai variabel yang lain akan turun.

\section{HASIL PENELITIAN DAN \\ PEMBAHASAN}

\section{Rendemen Ekstrak Flavoonoid}

Rendemen dihitung dengan cara bobot hasil dibagi dengan bobot awal, dengan menggunakan alat destilasi vakum pada suhu $50-55^{\circ} \mathrm{C}$ dan tekanan 0,06 $\mathrm{Pa}$ dengan variable waktu maserasi 4 , 8, 12, 16, 24 jam. Hasil rendemen disajikan pada tabel 1. Dari hasil yang didapat, rendemen berkisar antara 2,33 - 7,83 \% massa. Hasil yang didapat mendekati dengan yang didapat oleh Rachman dkk, rendemen ekstrak simplisia rimpang temu ireng menggunakan pelarut metanol sebesar 
$2,54 \%$ massa dan pelarut $n$-heksana sebesar 5,72 \% massa (2008). Rendemen terkecil yang didapat lebih rendah dibandingkan dengan rendemen ekstrak metanol yang didapat oleh Rachman dkk tetapi rendemen yang tersebsar yaitu 7,83 \% massa lebih tinggi dibandingkan dengan ekstrak $n$ - heksana.

Tabel 1. Hasil Rendemen Ekstrak Flavonoid dengan Variabel Waktu Maserasi

\begin{tabular}{|c|c|c|}
\hline No. & $\begin{array}{c}\text { Waktu } \\
\text { maserasi (jam) }\end{array}$ & $\begin{array}{c}\text { Rendemen (\% } \\
\text { massa })\end{array}$ \\
\hline 1. & 4 & 2,33 \\
\hline 2. & 8 & 3,67 \\
\hline 3. & 12 & 4,16 \\
\hline 4. & 16 & 5,83 \\
\hline 5. & 24 & 7,83 \\
\hline
\end{tabular}

Nilai absorbansi larutan standar kuersetin dapat dilihat pada tabel 2

Tabel 2. Hasil Absorbansi Larutan Standar Kuersetin

\begin{tabular}{|c|c|c|}
\hline No. & $\begin{array}{c}\text { Konsentrasi } \\
\text { larutan } \\
\text { kuersetin }\end{array}$ & Absorbansi \\
\hline 1. & $1 \mathrm{ppm}$ & $0,280 \mathrm{~nm}$ \\
\hline 2. & $2 \mathrm{ppm}$ & $0,330 \mathrm{~nm}$ \\
\hline 3. & $3 \mathrm{ppm}$ & $0,430 \mathrm{~nm}$ \\
\hline 4. & $4 \mathrm{ppm}$ & $0,510 \mathrm{~nm}$ \\
\hline 5. & $5 \mathrm{ppm}$ & $0,770 \mathrm{~nm}$ \\
\hline
\end{tabular}

Hasil perhitungan kadar flavonoid dapat dilihat pada tabel 3.

Tabel 3. Hasil Perhitungan Kadar Flavonoid dengan Variabel Waktu Maserasi

\begin{tabular}{|c|c|c|c|}
\hline No & $\begin{array}{c}\text { Waktu } \\
\text { maseras } \\
\text { i (jam) }\end{array}$ & $\begin{array}{c}\text { Nilai } \\
\text { Absorbans } \\
\text { i (nm) }\end{array}$ & $\begin{array}{c}\text { Kadar } \\
\text { Flavonoi } \\
\text { d ( g/ml) }\end{array}$ \\
\hline 1. & 4 & 0,277 & 1,38 \\
\hline 2. & 8 & 0,311 & 1,68 \\
\hline 3. & 12 & 0,440 & 2,79 \\
\hline 4. & 16 & 0,448 & 3,20 \\
\hline 5. & 24 & 0,522 & 3,50 \\
\hline
\end{tabular}

Ekstrak dengan kadar flavonoid terbaik lalu diaplikasikan sebagai bahan tambahan (antioksidan) dalam pembuatan sabun transparan. Pengujian yang dilakukan terhadap sabun padat transparan yang didapat berupa $\mathrm{pH}$, kadar air dan alkali yang mengacu pada SNI 06-3532-1994. Dari hasil pengujian diperoleh hasil pada tabel 4 .

Tabel 4. Hasil Uji Kualitas Sabun Padat Transparan dengan Penambahan Ekstrak Temu Ireng

\begin{tabular}{|c|c|c|c|}
\hline No. & $\begin{array}{c}\text { Kriteria } \\
\text { pengujian }\end{array}$ & $\begin{array}{c}\text { Hasil } \\
\text { Uji }\end{array}$ & $\begin{array}{c}\text { SNI 06- } \\
3532- \\
1994\end{array}$ \\
\hline 1. & pH & 9 & $8-10$ \\
\hline 2. & Alkali & 0,048 & Maks 0,1 \\
\hline 3. & Kadar Air & 0,31 & Maks 15 \\
\hline
\end{tabular}

Pembahasan

1. maserasi terhadap rendemen flavonoid

Penelitian ini dilakukan dengan variabel lama waktu maserasi yaitu 4, 8, 12, 16 dan 24 jam dengan bahan baku bubuk temu ireng sama sebanyak 6 gam. Filtrat yang sudah disaring sampai bersih kemudian dipisahkan dengan pelarutnya yaitu metanol dengan destilasi vakum pada temperatur $50-55{ }^{\circ} \mathrm{C}$ tekanan 0,06 Pa. Hasil berupa ekstrak kental kemudian dihitung rendemennya pada persamaan (1). Hasil perhitungan rendemen dapat dilihat pada tabel 1. Pengaruh waktu maserasi terhadap rendemen dapat dilihat pada gambar 1 .

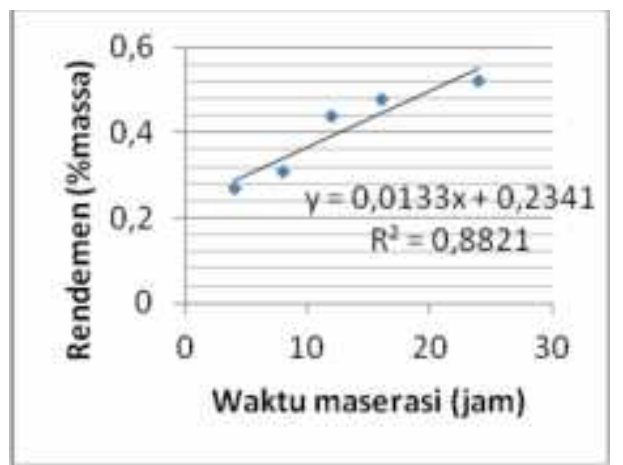


Gambar 1. Pengaruh waktu maserasi terhadap rendemen ekstrak temu ireng

Dari gambar 1 waktu maserasi mempengaruhi hasil rendemen ekstrak temu ireng yang didapat, tampak bahwa secara kualitatif rendemen yang didapat pada waktu 4 jam adalah yang paling rendah yaitu $2,33 \%$. Kenaikan waktu maserasi dua kali lipat (8 jam) menaikkan rendemen sebesar $1,34 \%$. Selisih kenaikan rendemen tertinggi yaitu terjadi pada waktu 24 jam dari 16 jam yaitu sebesar $2 \%$. Dari gafik terlihat bahwa rendemen terus mengalami kenaikan dengan bertambahnya waktu maserasi. Sehingga hubungan antara waktu maserasi dan rendemen dapat dinyatakan dalam persamaan linear $y=0.0028 x+0.012$ dengan harga $R^{2}=0,9893$. Penelitian Rachman dkk (2008) tidak menggunakan variabel waktu maserasi, sehingga tidak dapat dibandingkan hasilnya. Kenaikan rendemen terjadi secara linear yang berarti semakin lama waktu maserasi maka semakin tinggi rendemen yang didapatkan. Hal ini disebabkan semakin lama waktu maserasi maka memberikan waktu yang cukup untuk kontak antara bahan baku dengan pelarutnya. Sehingga waktu yang diberikan cukup untuk membuat pelarut menembus permukaan bahan yang dimaserasi dan menarik keluar senyawa - senyawa yang terkandung di dalam bahan.

2.

flavonoid Hasil uji kadar

Nilai absorbansi dapat dilihat pada tabel 2. Nilai absorbansi terendah didapat pada waktu maserasi 4 jam yaitu $0,277 \mathrm{~nm}$ dan yang tertinggi pada waktu maserasi 24 jam yaitu $0,522 \mathrm{~nm}$. Dari data ini dihitung kadar flavonoid per-sampel menggunakan rumus pada persamaan 1. Hasil nilai absorbansi dapat disajikan dalam Gambar 2.

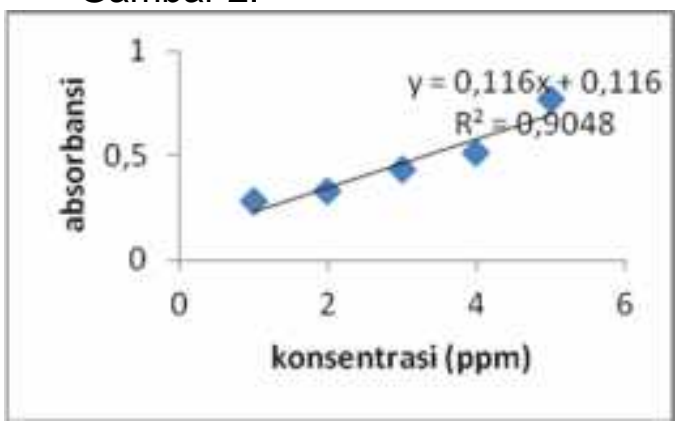

Gambar 2. Kurva larutan standar kuersetin

3.

\section{Uji Kadar Flavonoid}

Setelah dihitung didapat kadar antosianin tiap sampelnya, pada waktu maserasi 4 jam didapatkan kadar sebesar $1.38 \mathrm{~g} / \mathrm{mL}$, dan sampel waktu maserasi 24 jam didapatkan kadar tertinggi $3.5 \mathrm{~g} / \mathrm{mL}$. dari data tesebut didapat kadar flavonoid terbaik pada waktu maserasi 24 jam yaitu $3.5 \mathrm{~g} / \mathrm{mL}$ dan gafik hubungan antara gafik hubungan antara kadar flavonoid dengan waktu maserasi pada Gambar 3.

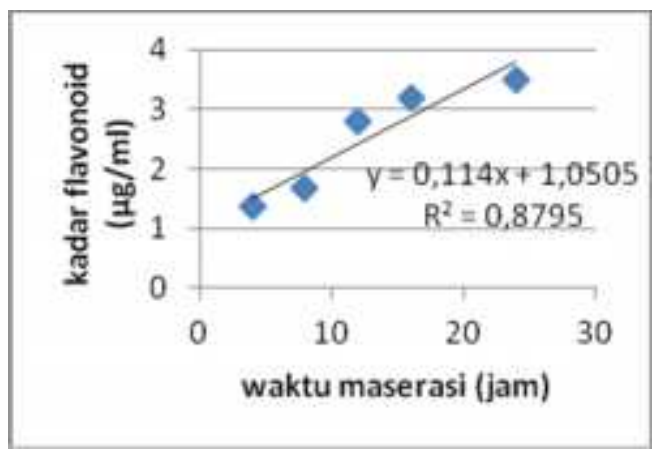

Gambar 3. Pengaruh waktu maserasi terhadap kadar flavonoid.

Dari gambar 3 didapat persamaan $\mathrm{y}=$ $0.114 x+1.050$ dengan $R^{2}=0.879$. Dari hasil penelitian dapat dilihat bahwa semakin lama waktu maserasi maka kadar flavonoid yang didapat semakin banyak. Ini menandakan bahwa dari ekstrak kental yang didapatkan memiliki kandungan flavonoid yang berbeda di setiap variasi waktu selama maserasi. 
Dari hasil penelitian dapat dilihat bahwa semakin lama waktu maserasi yang digunakan maka akan semakin besar kadar flavonoid yang didapatkan. Hasil yang didapatkan pada masing-masing waktu maserasi juga tidak berbeda jauh dari satu titik ke titik lainnya dikarenakan flavonoid tersebut dapat larut dengan baik dalam metanol karena kepolaran pelarut tersebut, maka kadar zat yang terlarut makin besar dan semakin lama waktu yang digunakan maka makin besar konsentrasi zat tersebut.

\section{$4 . \quad$ Pengujian \\ Karakteristik Sabun}

Hasil ekstrak dari proses maserasi yang sudah di hitung rendemen dan kadarnya kemudian diambil sampel dengan kadar flavonoid terbaik sebagai aditif zat antioksidan dalam pembuatan sabun transparan. Dalam pembuatan sabun transparan dibuat menjadi 2 sabun. Sabun pertama dibuat tanpa penambahan ekstrak flavonoid dan sabun kedua dengan penambahan kadar flavonoid terbaik yaitu 3,5 $\mathrm{g} / \mathrm{ml}$. Setelah itu dilakukan pengujian kualitas sabun meliputi Bilangan Penyabunan, pH, Kadar Air, dan Alkali Bebas.

\section{a. Uji Bilangan Penyabunan}

Saponifikasi (saponification) adalah reaksi yang terjadi ketika minyak atau lemak dicampur dengan larutan alkali. Bilangan penyabunan digunakan untuk menentukan berat molekul minyak dan lemak secara kasar. Bilangan penyabunan dinyatakan sebagai banyaknya (mg) $\mathrm{KOH}$ yang dibutuhkan untuk menyabunkan satu gam lemak atau minyak. Sampel yang dipergunakan untuk penentuan bilangan penyabunan adalah minyak kelapa. Alkohol yang ada pada $\mathrm{KOH}$ berfungsi untuk melarutkan asam lemak hasil hidrolisis agar mempermudah reaksi dengan basa sehingga membentuk sabun. Bilangan penyabunan minyak yang akan dijadikan bahan baku pembuatan sabun transparan diperoleh sebesar $252 \mathrm{mg} \mathrm{KOH} / \mathrm{g}$ minyak.

b. $\mathrm{Uji} \mathrm{pH}$

Nilai $\mathrm{pH}$ merupakan nilai yang menunjukkan derajat keasaman suatu bahan. Produk kosmetika memiliki karakteristik fisik yang sangat penting, yaitu nilai $\mathrm{pH}$. Nilai $\mathrm{pH}$ yang sangat tinggi atau sangat rendah dapat menambah daya absorbansi kulit sehingga memungkinkan kulit teriritasi. Namun $\mathrm{pH}$ merupakan parameter yang sangat penting untuk menentukan kelayakan penggunaan sebagai sabun mandi (Soemarjo, W.S dan Harnawi, 2009). Dari hasi penelitian ini dibuat dua sampel sabun transparan yang memiliki derajat keasaman yang sesuai dengan standar derajat keasaman yaitu 8-10 (SNI,1996). Yang dapat dilihat pada tabel 5.

Tabel 5. Nilai pH pada sabun transparan

\begin{tabular}{|l|l|l|}
\hline Sabun & $\begin{array}{l}\mathrm{Uji} \\
\mathrm{pH}\end{array}$ & $\begin{array}{l}\text { SNI 06-4085- } \\
1996\end{array}$ \\
\hline $\begin{array}{l}1 \text { (tanpa } \\
\text { ekstrak) }\end{array}$ & 9 & $8-10$ \\
\hline $\begin{array}{l}2 \text { (dengan } \\
\text { ekstrak) }\end{array}$ & 9 & $8-10$ \\
\hline
\end{tabular}

Dari tabel 5 dapat diketahui bahwa kedua sabun telah memenuhi syarat sesuai dengan SNI. Penambahan ekstrak flavonoid tidak memberikan pengaruh terhadap $\mathrm{pH}$. Dilihat dari klasifikasi sabun menurut $\mathrm{pH}$, sabun yang dihasilkan dalam penelitian ini baik untuk tubuh akan tetapi tidak memberikan efek lembut dikulit. 
Uji kadar air sabun padat transparan yang didapat disajikan di tabel 6. Prinsip penetapan kadar air adalah pengukuran massa setelah pengeringan pada suhu $105^{\circ} \mathrm{C}$ selama 2 jam. Berdasarkan SNI 06-3532-1994, kadar air yang diperoleh dalam sediaan sabun padat maksimal $15 \%$.

Tabel 6. Uji Kadar Air

\begin{tabular}{|l|l|l|}
\hline Sampel & $\begin{array}{l}\text { Uji Kadar } \\
\text { Air (\%) }\end{array}$ & $\begin{array}{l}\text { SNI 06- } \\
\text { 3532-1994 } \\
(\%)\end{array}$ \\
\hline $\begin{array}{l}\text { 1 (tanpa } \\
\text { ekstrak) }\end{array}$ & 35 & Maks. 15 \\
\hline $\begin{array}{l}\text { 2 (dengan } \\
\text { ekstrak) }\end{array}$ & 31 & Maks. 15 \\
\hline
\end{tabular}

Berdasarkan table 6 kadar air yang diperiksa terhadap sabun yang dibuat menunjukan hasil yang tidak memenuhi syarat SNI. nilai kadar air pada kedua sampel sabun yang dihasilkan memiliki nilai yang diatas standar maksimal yang di syaratkan. Kadar air sabun yang dihasilkan diduga dipengaruhi oleh kadar air bahan baku pada sabun yaitu minyak kelapa (VCO), ekstrak temu ireng, serta kepekatan larutan $\mathrm{NaOH}$ yang ditambahkan. Kandungan air yang tinggi dapat diperbaiki dengan menaikkan kepekatan larutan $\mathrm{NaOH}$ yang ditambahkan. Cavitch (2010) menyatakan sabun terbuat dari lemak dan minyak, alkali, serta air. Menurut Ibrahim, dkk. (2005), semakin tinggi kandungan air di dalam sabun, maka sabun tersebut semakin lunak dan semakin mudah larut dalam air. Menurut Badan Standardisasi Nasional dalam SNI 06-3532-1994, batas maksimal kandungan air dalam produk sabun mandi yaitu $15 \%$.

\section{KESIMPULAN (DAN SARAN)}

\section{Kesimpulan}

1. Ekstrak temu ireng mengandung flavonoid dengan kadar tertinggi 3,5 $\%$ massa.

2. Semakin lama waktu maserasi semakin besar rendemen yang didapatkan.

3. Hasil rendemen terbaik didapatkan pada waktu maserasi 24 jam sebesar $7,83 \%$ massa dengan persamaan $y=0.002 x+0.012$ dengan $R^{2}=0.989$ dan kadar flavonoid terbaik yang didapat adalah $3.5 \mathrm{~g} / \mathrm{mL}$ dengan persamaan $\mathrm{y}=0.114 \mathrm{x}+1.050$ dengan $R^{2}=0.879$.

4. Sabun padat transparan yang dihasilkan mempunyai $\mathrm{pH} 9$, kandungan alkali 0,048 dan kadar air 0,31\% massa.

\section{DAFTAR PUSTAKA}

Cavitch SM. 2010. The Soapmaker's Companion a Comprehensive Guide with Recipes, Tecniques and Know How. North Adams (US) : Storey Book.

Geissman,T.A. 1962. The Chemistry of Flavonoid Compounds. The Macmillan Company. New York.

Gunawan, D., Sugiharjo, C.J., Mulyani, S., Koensoemanyah. 1989. Empon - Empon dan Tanaman Lain dalam Zingiberaceae. Edisi I. Perhimpunan Peneliti Bahan Obat Alam (PERHIBA) Komisariat Yogyakarta bekerja sama dengan IKIP Semarang Press. Semarang.

Ibrahim, B., Suptijah, P., dan Hermanto, S. 2005. Penggunaan Bentonit dalam Pembuatan Sabun dari Limbah Netralisasi Minyak Ikan Lemuru (Sardinella sp)., Buletin Teknologi Hasil Perikanan, Vol. VIII Nomor 2 Tahun 2005.

Nugahaningtyas, K.D., Matsjeh, S. dan Wahyuni, T.D. 2005. Isolasi dan Identifikasi Senyawa Flavonoid dalam Rimpang Temu Ireng (Curcuma 
aeruginosa Roxb). Biofarmasi Volume 3 No 1: 32-38, Februari 2005. Jurusan Biologi FMIPA UNS. Surakarta.

Syamsuhidayat, S.S., Hutapea, J.R. 1991. Inventaris Tanaman Obat Indonesia. Jilid I. Badan Penelitian Obat Pengembangan Kesehatan. Departemen Kesehatan RI. Jakarta.

Rachman, F., Logawa, E.D., Hegartika, H. dan Simanjuntak, P. 2008. Aktivitas Antioksidan Ekstrak Tunggal dan Kombinasinya dari Tanaman Curcuma spp. Jurnal IImu Kefarmasian Indonesia, September 2008. Vol.6 No.2. hal. 69-74.

Robinson, T. 1995. Kandungan Organik Tumbuhan Tinggi. Penerjemah: Padmawinata,K. Penerbit ITB. Bandung.

Wijana, S., Soemarjo., dan Harnawi, T. 2009. Studi Pembuatan Sabun Mandi Cair dari Daur Ulang Minyak Goreng Bekas (Kajian Pengaruh Lama Pengadukan dan Rasio Air:Sabun Terhadap Kualitas). Jurnal Teknologi Pertanian Vol.10 No.1 (April 2009): $54-61$.

Willaman, S.S. 1955. Some Biological Effects of The Flavonoids. Journal of the American Pharmaceutical Assoc, Sci.Ed.44, 1955:404 - 409. America. 